\section{Vernalization of Fragments of Embryo Tissue}

Embryos of cereal grains, separated from the endosperm and cultured on a medium containing sugar, can be vernalized by exposure to a temperature of $1^{\circ} \mathrm{C}$. in the same way as whole grains ${ }^{1,2,3,4}$. In order to locate more precisely the tissues concerned in the process, embryos of Petkus winter rye were mutilated in various ways before vernalization treatment. In this preliminary experiment only two embryos were subjected to each type of mutilation.

\begin{tabular}{|c|c|c|}
\hline Treatment & $\begin{array}{l}\text { No. of } \\
\text { replicates }\end{array}$ & $\begin{array}{l}\text { Condition of plants } 84 \text { days } \\
\text { after end of treatment }\end{array}$ \\
\hline A. Vernalized 6 weeks & & \\
\hline 1. Whole embryos & 7 & All past anthesis. \\
\hline $\begin{array}{l}\text { 2. Stem apex and } \\
\text { fourth leaf re- } \\
\text { tained }\end{array}$ & 2 & Both with ears emerged. \\
\hline 3. Scutellum removed & 2 & $\begin{array}{l}\text { One vegetative, one shoot- } \\
\text { ing. }\end{array}$ \\
\hline 4. Scutellum and shoot & 2 & No plants obtained. \\
\hline $\begin{array}{l}\text { 5. Scutellum and roots } \\
\text { removed }\end{array}$ & 2 & $\begin{array}{l}\text { One with ear emerged, one } \\
\text { shooting. }\end{array}$ \\
\hline $\begin{array}{c}\text { 6. Scu tellum } \\
\text { coleoptile } \\
\text { moved }\end{array}$ re- & 2 & $\begin{array}{l}\text { One with ear emerged, one } \\
\text { vegetative. }\end{array}$ \\
\hline $\begin{aligned} \text { B. } & \text { Vernalized } 2 \text { weeks } \\
\text { 1. } & \text { Whole embryos }\end{aligned}$ & 14 & All vegetative. \\
\hline
\end{tabular}

The fragments were planted on agar medium containing 2 per cent sucrose, vernalized at $1^{\circ} \mathrm{C}$. for six weeks, and after eight further days growth on the medium at a temperature of approximately $18^{\circ} \mathrm{C}$., were large enough to be planted out. The appearance of the fragments at the end of the vernalization period is shown in the figure. The removal of the coleoptile has the curious effect of promoting hypertrophy of the tissue about the roots, and there is, in addition, a lack of gravity perception in the first leaf. Possibly the latter effect is simply due to the absence of the mechanical support of the coleoptile, but it is interesting to noie that whole embryos, germinated on 2 per cent sucrose with the addition of $1 / 10,000$ hetero-

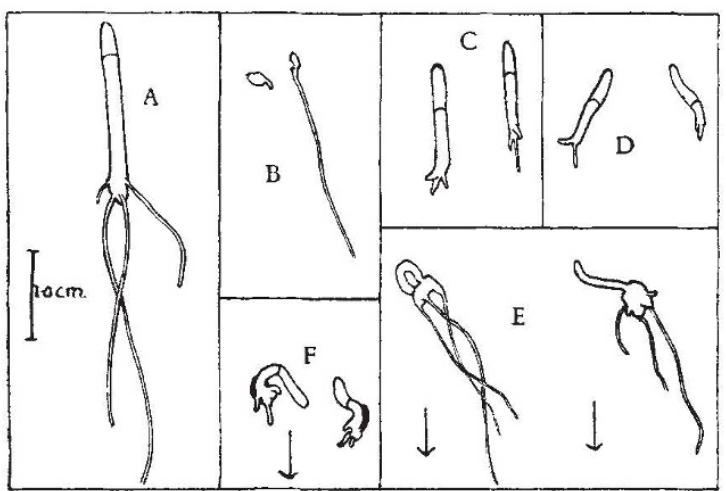

CAMERA LUCIDA DRAWINGS OF EMBRYO FRAGMENTS AT END OF SIX WEEKS VERNALIZATION AT $1^{\circ} \mathrm{C}$. $A$, COMPLETE EMBRYO; $B$, STEM APEX AND FOURTH LEAF INITIAI; $C$, SCUTELLUM REMOVED ; $D$, SCUTELLUM AND ROOTS REMOVED; $E$, SCUTELLUM AND COLEOPTILE REMOVED ; $F$, COMPLETE EMBRYOS GROWN FOR SIX WEEKS AT $1^{\circ} \mathrm{C}$. ON MEDIUM CONTAINING 1/10,000 HETERO-AUXIN (FOR COMPARISON WITH $E$. IN $E$ AND $F$ THE ARROW INDICATES THE DIRECTION OF THE GRAVITATIONAL PULL). auxin solution, show a similar failure of gravitational response as well as the hypertrophy of the coleorrhiza (see accompanying figure, $F$ ).

Only those embryos from which the stem apex had been removed failed to produce green plants, but their roots continued growth in the sucrose medium for many weeks. Plants arising from the isolated stem apex were dwarfed; each consisted of a main stem and one tiller, and in one the main axis bore an ear on a stem about four inches high, with six leaves. The progress towards flowering made by each plant during 84 days from the end of vernalization is shown in the table; no further observations were made. Comparison with plants grown from embryos vernalized for two weeks makes it clear that vernalization treatment has accelerated flowering but that the process was less effective than in the case of complete embryos.

O. N. Purvis.

Research Institute of Plant Physiology, Imperial College of Science and Technology, London.

${ }^{1}$ Gregory, F. G., and Purvis, O. N., Nature, 138, 249 (1936).

${ }^{2}$ Gregory, F. G., and Purvis, O. N., Ann. Bot., N.S. (2), 237 (1938).

${ }^{3}$ Gregory, F. G., and de Ropp, R. S., NATURe, 142, 481 (1938).

'Konovalov, I. N., C.R. Acad. Sci., U.R.S.S., 16, 381 (1937).

\section{Permeability of Insect Cuticle}

ONE of the major problems in research on insecticidal action concerns the correlation of the toxicity of an insecticide with its chemical and physical properties. Very little progress has hitherto been made when relatively non-toxic carriers have been used. This is mainly due to the fact that too little physiological significance has been attached to the mode of action of the carriers in relation to the toxic principle under investigation.

A study of the toxicities of various constituents of heavy naphtha to the nymphal and adult stages of the bed-bug, Cimex lectularius, L., has shown that the toxicity of unsaturated compounds, such as indene, may be materially increased by the addition of non-toxic mixtures of paraffins and cycloparaffins. The assumption that the unsaturated compound was assisted through the cuticle by the more apolar substances present in heavy naphtha led to an investigation of the general physiology and permeability of the insect cuticle. The results show that feebly dissociating compounds of high dielectric constant penetrate the cuticle much more readily in the presence of relatively apolar substances of low dielectric constant, the main region of induced penetration being at the cuticle-hæmolymph interface. This generalization applies both to fumigant and contact action, and may be conveniently illustrated by a model experiment, using as test insects, larvæ of the blowfly, Calliphora erythrocephala, Meig.

When a larva is immersed in ethyl alcohol, penetration through the cuticle and tracheal system takes place very slowly, and the insect generally remains active for at least an hour. The effect of paraffins of the kerosene type is even less pronounced, and loss of reaction to a mechanical stimulus may take two hours or more. With a mixture of ethyl alcohol and paraffins, penetration of the alcohol is so rapid that the insect dies within a few seconds, swells perceptibly, and eventually bursts within four to six 